\title{
Semantic Study of Halu' in The Qur'an
}

\author{
Naifah \\ Universitas Islam Negeri Walisongo Semarang \\ Corresponding author: naifah@walisongo.ac.id
}

\begin{abstract}
The study aimed to find out the meaning of halu' in the Qur'an, the relationship between halu and Adversity Quotient (AQ), and the Qur'anic management methods to address halu' as well as to enhance the Adversity Quotient (AQ). This study was a descriptive qualitative research with semantic approach. The data were collected through documentation method and analized by means of Syntagmatic Paradigmatic approach. The study found that halu' was a negative human potential to easily complain but hard to share with others because it was triggered by greed. It had potential to cause people to quickly give up, despair, and be selfish, thus causing self-difficulties to face challenges of life. It hampered an individual to be a strong personality and to achieve personal success. Therefore, human needed for specific methods to suppress and manage the negatif potential to avoid its negative effects. Halu' and AQ (Adversity Quotient) had a very close relationship. Halu' could be overcome by improving the level of Adversity Quotient (AQ). Thus, a high Adversity Quotient (AQ) was the solution for the problem of human's halu'. The Qur'anic management methods in addressing halu' used to improve Adversity Quotient (AQ) were performing prayers, establishing prayers continuously, spending the property for infaq, believing in the day of judgment, feeling fear of the God's punishment, having sexual intercourse only with a legitimate partner, fulfilling the mandate and promises, enforcing bear testimony, and keeping the prayers quality.
\end{abstract}

Penelitian ini bertujuan untuk mengetahui makna halu 'dalam Alquran, hubungan antara halu dan Adversity Quotient (AQ), dan metode manajemen Alquran untuk mengatasi halu' serta untuk meningkatkan Adversity Quotient (AQ) . Penelitian ini adalah

ISSN 2622-6146 (e) 2622-6138 (p)

(C) 2019 Alsina : Journal of Arabic Studies

http://journal.walisongo.ac.id/index.php/alsina 
penelitian kualitatif deskriptif dengan pendekatan semantik. Data dikumpulkan melalui metode dokumentasi dan dianalisis dengan menggunakan pendekatan Paradigmatic Syntagmatic. Studi ini menemukan bahwa halu 'adalah potensi manusia yang negatif untuk dengan mudah mengeluh tetapi sulit untuk dibagikan kepada orang lain karena dipicu oleh keserakahan. Itu berpotensi menyebabkan orang cepat menyerah, putus asa, dan egois, sehingga menyebabkan kesulitan diri menghadapi tantangan hidup. Itu menghambat seseorang untuk menjadi kepribadian yang kuat dan untuk mencapai kesuksesan pribadi. Oleh karena itu, manusia memerlukan metode khusus untuk menekan dan mengelola potensi negatif untuk menghindari efek negatifnya. Halu 'dan AQ (Adversity Quotient) memiliki hubungan yang sangat dekat. Halu 'dapat diatasi dengan meningkatkan tingkat Adversity Quotient (AQ). Dengan demikian, Adversity Quotient (AQ) yang tinggi adalah solusi untuk masalah halu manusia '. Metode manajemen Alquran dalam menangani halu 'yang digunakan untuk meningkatkan Adversity Quotient (AQ) adalah melakukan doa, membangun doa secara terus menerus, membelanjakan harta untuk infaq, percaya pada hari penghakiman, merasa takut akan hukuman Tuhan, merasa takut akan hukuman Tuhan, hanya melakukan hubungan seksual saja dengan mitra yang sah, memenuhi mandat dan janji, menegakkan kesaksian beruang, dan menjaga kualitas doa.

Keywords: adversity quotient; halu'; Qur'anic method.

\section{Introduction}

Solving and fighting against adversity are very important for human beings' life because their happy life depends on how well they can solve and fight against the problems which they are facing. ${ }^{1}$ Anyone who can confront and fight against the problem wisely will be successful. This is especially true in our today's world; people should adapt themselves to busy life. They have to manage their life and solve the problem wisely when they face it.

${ }^{1}$ Koonthaisong, M. 2003. Some Mental Features that Correlated to the Adversity Quotient. M.Ed. Thesis. Mahasarakham: Mahasarakham University, Thailand, unpublished document. 
Halu' is one of human negative potentials stated by the Qur'an. Halu' will make someone lazy, selfish, paralyzed, pessimists, fear of challenges, reluctant to open themselves, and less care with surrounding environment. Such characteristics are owned by those whose halu' is in acute level. Therefore, improving Adversity Quotient is absolutely necessary for human beings to deal with weaknesses, failures and obstacles of life. This study examines what a halu' is and the Qur'anic method to improve the Adversity Quotient as one of the determining factors of success in preventing halu'. Understanding the concept of halu' will help to better react to challenge and adversity in all aspects of life. Ability to respond the adversity is a strong indicator of ability to succeed in many endeavors.

\section{Method}

This study is a descriptive qualitative research with semantic approach. The data are collected through a documentation method and analized by means of Syintagmatic Paradigmatic approach. Semantics is a sub discipline of linguistics which focuses on the study of meaning. ${ }^{2}$ Semantics tried to understand meaning as an element of language and how it is constructed by language as well as interpreted, obscured and negotiated by speakers and listeners of language. Semantics is closely linked with another sub discipline of linguistics, pragmatics. However, unlike pragmatics, semantics is a highly theoretical research perspective, and looked at the meaning of language in isolation. Pragmatics is a more practical subject and interested in meaning of language in use. ${ }^{3}$

2 http://mohmansurfauzi.blogspot.com/2014/11/pendekatan-semantik-dalam-kajian-islam.html

3 https://sites.google.com/a/sheffield.ac.uk/all-about-linguistics/branches/semantics/what-is-semantics 
Ferdinand de Saussure states that there are two fundamental types of relations between words that he believes correspond to basic operations of our brain: syntagmatic and paradigmatic associations. A syntagmatic relation between two words happens when they occur in spoken or written language more frequently than what is expected from chance and has different grammatical roles in the sentences in which they occur. The typical examples are the word pairs of coffee-drink, sun-hot, or teacher-school. The relation between two words is paradigmatic where the two words can substitute for one another in a sentence without affecting the gramaticality or acceptability of the sentence. ${ }^{4}$ All of the words in a paradigm are semantically related, so the guiding principle of the association is meaning. Since the system is open-ended, it is relatively easy to add newly-acquired words to the paradigmatic networks in a learner's mental lexicon. This type of association promotes efficient expansion and retrieval of words and is particularly valuable in developing a large receptive vocabulary. 5

\section{Disscusion}

Halu' in the Qur'an

The word of Halu' is mentioned only once in the Qur'an, namely in chapter of al-Ma'arij verse 19: ان الانسان خلق هلوعا "Truly man was created to be halu '".6 Nafi' bin Azraq argues that this verse is revealed regarding Abu Jahl ibn Hisham, a Quraish figure. However, the opinion about the owner of halu' is divided

\footnotetext{
${ }^{4}$ Reinhard Rapp, The Computation of Word Association: Comparing Syntagmatig and Paradigmatic Aproaches (University of Mainz, FASK. D76711 Germersheim Germany, ucrel.lancs.ac.uk/acl/C/CO2/C02 1007.pdf), p. 1.

5 Theoretical Underpinnings of Vocabula;ry Learning and Teaching (http://cd1.edb.hkedcity.net/cd/eng / vocab09/ch1_3-2.htm

6 Siti Chamamah Suratno (next; Chamamah), Ensiklopedi al-Qur'an Dunia Islam Modern Vol II (Yogyakarta: Dana Bhakti Prima Yasa, 2005), p. 285.
} 
into two categories. The first opinion states that halu' is owned only by the infidels. The scholars who supports this opinnion are al-Qurtubi, al-Dlahak, and al-Kalabi. ${ }^{7}$ The second opinion argues that halu' is possessed by all kinds of people. Ali al-Shabuni, one of the scholars supporting the idea, uses exception (istitsna) after lafadz halu' as the reasons. He argues that exception (istitsna) is one of the criteria of generality, so halu' is owned by the people in general. ${ }^{8} \mathrm{Al}$-Fara' also posites that halu' is possessed by all kinds of people; the same as "losses" that are suffered by all human beings, unless certain criteria set out in the Qur'an of al-'Ashr chapter verses 1 to $5 .{ }^{9}$ I do agree with this second opinion because it is based on the strong arguments and reasons (dalalah).

Scholars are divided into two different opinions in perceiving whether halu' is a true nature of human since creation or a latent potential (hal muqaddarah) only. The scholars who support the first opinion are al-Hasan ${ }^{10}$ and Ali as-Shabuni1,

${ }^{7}$ Abu Abdillah Muhammad bin Ahmad al-Anshari al-Qurthubi (next; al-Qurthubi), Tafsir al-Qurthubi: al-Jami' li Ahkam al-Qur'an Juz 71 (Kairo: Dar al-Sya'bi, t.th.), p. 6768. Also look at Abu al-Hasan Ali bin Muhammad bin Habib al-Mawardi al-Bashri (next; al-Mawardi), Al-Nukat wa al-'Uyun Tafsir al-Mawardi Vol VI (Beirut: Dar al-Kutub al-'Ilmiyyah, t.th.), p. 94.

${ }^{8}$ Muhammad Ali al-Shabuni, Shafwatu al-Tafasir Vol III (Beirut: Dar al-Qur'an al-Karim, Cet. II, 1981), p. 444.

${ }^{9}$ Abu Zakaria Yahya bin Ziad al-Farra', Ma'ani al-Qur'an Juz III (t. tp.: Turatsuna, t. th.), p. 185

${ }^{10} \mathrm{Abd}$ al-Rahman bin Kamal Jalal al-Din al-Suyuthi (next: al-Suyuthi), Tafsir al-Dur al-Mantsur fi Tafsir al-Ma'tsur Juz VIII (Beirut: Dar al-Fikr, Cet. I, 1983), p. 283.

${ }^{11}$ Ali as-Shabuni, Shafwatu, p. 444. 
whereas those support the second opinion are Imam al-Jalalayn ${ }^{12}$ and Ibn Kathir. ${ }^{13}$ On the other hand, Ibrahim Muhana included halu' in the list of bad human characters. The characters here refer to the tendency and interest owned by most people, since they were created. ${ }^{14}$ With two different opinions above, I support the second opinion with following reasons:

1) Halu' is not an innate nature of humans that will be almost impossible to change it. By this state, the message of Prophet Muhammad will be very hard to be implemented in humans' life.

2) Halu' is a humans' inner potential that can be pressed and turned. Otherwise, the verses 21 to 34 of al-Ma'arij Chapter which can be used as solution to free mankind from the negative influences of halu' will not mean anything.

\section{Epistemological Meaning}

The word halu'a is a mubalaghah (hiperbolic form, means frequent, very, or infinite) patterns of hali'a-yahla'u-hala'an. ${ }^{15}$ The word halu's epistemological meaning expressed by mufassirin (the exoteric commentators) can be seen in the following table.

12 Syaikh Ahmad al-Shawi al-Maliki (next: al-Shawi), Khasyiyah alShawi 'ala Tafsir al-Jalalaini Juz VI (Beirut: Dar al-Fikr, Cet. I, 1988), p. 252. Also look at Sulaiman bin 'Amr al-'Ajili al-Syafi'i, Al-Futuhat alIlahiyyah bi Taudlihi Tafsir al-Jalalain li al-Daqaiq al-Khafiyyah Juz IV (Mesir: Mathba'ah 'Isa al-Babi al-Khilbi, t.th.), p. 406.

${ }^{13}$ Imam Abu al-Fada' al-Hafidh Ibnu Katsir al-Damsyqi (next: Ibnu Katsir), Tafsir al-Qur'an al-'Adhim Juz IV (Beirut: Maktabah al-Nur al'Ilmiyyah, Cet. I, 1992), p. 422. Adding that human rather than printed (has original character), but it is only God's warning to them. Also look at Syaikh Imam Abu Yahya Zakaria al-Anshari, Fatkhu al-Rahman bi Kasyfi ma Yaltabisu fi al-Qur'an (t. tp.: 'Alim al-Kutub, t. th.), p. 435.

${ }^{14}$ Dr. Ahmad Ibrahim Muhana, Al-Insan ( ), p. 71.

15 Chamamah, Ensiklopedi, p. 285. Also look at M. Quraish Shihab, Tafsir al-Mishbah: Pesan, Kesan, dan Kaserasian al-Qur'an Vol. 14 (Jakarta: Lentera Hati, 2002), p.441. 
No. Halu's meaning

1. ضجورا جزوعا (impatient and easy to complain / narrow minded).
The Mufassir

Nafi' bin Azraq ${ }^{16}$ and alFarra'17

2.

$\begin{array}{ll}\text { ضجورا (impatient) } & \text { Ikrimah }^{18}, \text { Qatadah } \\ & \text { M. Jawwad and } \\ & \text { Maghniyyah }\end{array}$

3. جزوعا (complain easily/ Qatadah ${ }^{21}$ and Mujahid22 narrow minded)

4. بخيل (very stingy) Al- Dlahak and al-Hasan ${ }^{23}$

5. شحيحا (very miserly), Sa'id bin Jabir24

\begin{tabular}{lll}
\hline 6. حريصا (greedy) & $\begin{array}{l}\text { Ibnu 'Abbas 25 and } \\
\text { 'Ikrimah'26 }\end{array}$ \\
\hline
\end{tabular}

7. ضعery weak)

Abu Al-Ghiyats ${ }^{27}$

${ }^{16}$ Al-Suyuthi, Tafsir al-Dur, p. 283.

${ }^{17}$ Al-Farra', Ma'ani, p 185. Also look at Ibnu Mandzur, Lisan al-'Arab al-Mukhith Vol II (t. tp.: --, t. th.), p. 819.

${ }^{18}$ Imam Abu Muhammad al-Husain bin Mas'ud al-Farra' al-Baghawi al-Syafi'i (next: al-Baghawi), Tafsir al-Baghawi al-Musamma Ma'alim alTanzili Juz IV (Beirut: Dar al-Kitab al-'Ilmiyyah, Cet. I, 1993), p. 363. Also look at Chamamah, Ensiklopedi, p. 819, al-Qurthubi, Tafsir al-Qurthubi, p. 6769.

${ }^{19} \mathrm{Al}-\mathrm{Mawardi}$, Al-Nukat, p. 94.

${ }^{20}$ M. Jawwad Maghniyyah, Al-Tafsir al-Kasyif Vol VII ( Beirut: Dar al'Ilm al-Malayin, Cet. I, 1970), p. 418.

${ }^{21}$ al-Baghawi, Tafsir al-Baghawi, p. 363.

${ }^{22}$ Al-Mawardi, Al-Nukat, p. 94.

${ }^{23}$ Al-Mawardi, Al-Nukat, p. 94., also look at al-Baghawi, Tafsir alBaghawi, p. 363.

${ }^{24}$ Al-Baghawi, Ibid., also look at Al-Suyuthi, Tafsir al-Dur, p. 283.

25 Al-Baghawi, Ibid.

${ }^{26}$ Al-Mawardi, Al-Nukat, p. 94.

${ }^{27}$ Al-Mawardi, Al-Nukat, p. 94. 
8. الهلوع: أشدّ الحرص واسواً Al-Qurthubi 28

الجزع (Severe greed and

acute narrow mind)

9.

Ali al-Shabuni29 and al-
Baghawi

(very greedy and

sorely lack of patience)

\section{2) Native Speakers Meaning}

To find the true meaning of the word halu', it is important to identify its usage in daily Arabic conversation to know how this word is understood by the native speakers. In arabic language, a camel will be referred to as naqatun halu ${ }^{31}$ 'or naqah hilwa' $a h^{32}$ if it walks fast and lightly. Hisham bin Abdul Malik say to Syabbah bin 'Aqqal when he want to kiss his hand, "wait a minute, Syabbah, the Arabs do not do that unless someone who is halu' and the 'ajams do not do so unless someone who is comply." In addition, this word is also found in a few famous arabic poems which are all lead to the meanings of the haste, the impatience and the discontent. ${ }^{33}$

3) Terminological Meaning.

${ }^{28}$ Al-Qurthubi, Tafsir al-Qurthubi, p. 6769.

${ }^{29}$ Ali al-Shabuni, Shafwatu, p. 444.

${ }^{30}$ Al-Baghawi, Tafsir al-Baghawi, p. 363.

${ }^{31}$ Ibnu Mandzur, Lisan, p. 819. Also look at Ahmad Musthafa alMaraghi, Tafsir al-Maraghi terj. Bahrun Abu Bakar, LC., dkk Juz XXIX (Semarang: Toha Putra, 1993), p. 123.

${ }^{32}$ Al-Qurthubi, Tafsir al-Qurthubi, p. 6769.

${ }^{33}$ Ibnu Mandzur, Lisan, p. 819. 
In order to get halu's terminological meaning, all mufassirin (commentators) agree ${ }^{34}$ that halu' has been interpreted by God through two verses, 20 and 21 after verse 19.

"Truly, Man was created impatient and avaricious(19), Irritable when evil touches him (20), and impeding others when good touches him (21)." (The Qur'an, AlMa'arij Chapter: verses 19-21).

Jabir al-Jaza'iri adds the explanation of its meaning by someone who is quickly complaining and very lack of giving because he is very fond of treasure. ${ }^{35}$ Ibn Abbas expresses it in different words: when a man is stricked by poverty, he will be impatient but when he is given a wealth, he won't be charity. ${ }^{36}$ Those two things are special characteristics of the owner of $h a-$ $l u '{ }^{37}$ Citing Tsa'lab's opinion on halu', Ubaidah emphasizes by stating if a man receives kindness, he will be ungrateful but when he is stricken by misfortune he will be impatient. ${ }^{38}$ In other literature, Tsa'lab also asserts that God has interpreted

34 This agreement can be seen directly in the the existing books of interpretation, including Abu Bakr Jabir al-Jaza'iri, Aisar at-Tafasir li alKalam al-'Aliy al-Kabir (Madinah al-Munawwarah: Maktabah al-'Ulum wa al Hikam, 1994), p. 433, al-Baghawi, Tafsir al-Baghawi, p. 364, Ali al-Shabuni, Shafwatu, p. 445, al-Suyuti, Tafsir al-Dur, p. 283, al-Mawardi, Al-Nukat, p. 94, Maghniyyah, Al-Tafsir al-Kasyif, p. 417, al-Ansari, Fatkhu alRahman, p. 435, Ibn Kathir, Tafsir al-Qur'an, p. 422, al-Farra ', Ma'ani, pp 185, al-Shawi, Khasyiyah, p. 252, and al-Qurtubi, Tafsir al-Qurtubi, p. 6769. The syntagmatic analysis is alsofound in Ibn Mandzur, Lisan, p. 819 and Chamamah, Encyclopedia, p. 285.

35 Jabir al-Jaza'iri, Aisar, p. 433.

${ }^{36}$ Al-Baghawi, Tafsir al-Baghawi, p. 364. Also look at al-Suyuthi, Tafsir al-Dur, p. 283 dan al-Mawardi, Al-Nukat, p. 94.

${ }^{37}$ Al-Farra', Ma'ani, p 185, al-Shawi, Khasyiyah, p. 252, dan Ibnu Mandzur, Lisan, p. 819.

38 Chamamah, Ensiklopedi, p. 285. In harmony with opinion of 'Athiyyah in al-Mawardi, Al-Nukat, p. 95. 
this word by describing when a man is in distress, he will complain excessively; but when he receives any gifts, he will be very stingy and reluctant to share with others. ${ }^{39}$

Jawwad Maghniyyah argues that God shows that a man is weak by his conduct, as stated in Chapter Al-Nisa 'verse 27; الله الذى خلقكم من and Chapter Al-Rum verse 54 وخلق الانسان ضعيفا ضعف. When he meets the cause of its appearance such as poverty or wealth, the weakness will appear. When he is rich, he will be reluctant to give as he is fear to be poor. When he is poor, he will be despair and hopeless. ${ }^{40}$

Ibn Kaisan says that When God creates human beings, they are equipped with interest towards all good things that make easy and satisfying, and dislike things that are bad and difficult. Then God will consider him as the true servant if he will donate anything he likes and be patient over what is hated. ${ }^{41}$

a) Halu' and the Adversity Quotient.

There is no one who has never meet obstacles and failures in achieving purposes, accomplishments and success. In a business world, for example, there is a report stating: "Only 1 out of 10 new businesses will ever see a profit. An investor will only make a substantial profit off 1 out of every 1000 plans that they are presented with. Most of the best positions will never be posted on a job board." Each of us may find a lot of problems in various forms. Those who cannot control their emotion while facing serious problems tend to escape by doing wrong things. ${ }^{42}$ In addition, there are countless heavy situations to be faced in human's life such as having broken home relationship, losing someone they love, living in poverty, losing status fear

${ }^{39}$ Al-Qurthubi, Tafsir al-Qurthubi, p. 6769. Also look at al-Maraghi, Tafsir al-Maraghi, p. 123.

40 Maghniyyah, Al-Tafsir al-Kasyif, p. 418.

${ }^{41}$ Al-Qurthubi, Tafsir al-Qurthubi, p. 6769. Also look at al-Baghawi, Tafsir al-Baghawi, p. 364, Ali al-Shabuni, Shafwatu, p. 445.

${ }^{42}$ Green, A. 2006. Effective personal communication skills for public relations. Creative print and design, USA. ISBN: 0-7494-4407-X 
and so on. With such great life challenges, humans need to manage their halu' potential to be a formidable individuals who are able to overcome obstacles and problems for success. Otherwise, they would be dragged by halu' towards pessimism and cast as a desperate loser. The ability to deal with such challenges will often be a determining factor in how successful the life is. Nowadays, Paul G. Stoltz develops a theory called Adversity Quotient (AQ) which refers to a reflection of someone who is facing a problem. ${ }^{43} \mathrm{He}$ is the one who coins the term as he advocates as well as the father of the AQ. ${ }^{44}$ The AQ need to be sharpened and upgraded as it is an important factor in determining success.

One example stated in the previous study shows that in addressing the challenges of business world, for business community and other organizations, the $A Q$ can help to expand people capacities to do more effectively, develop resilient leaders, create resilient and high-performing teams, accelerate change and fortify their culture, strengthen morale and reduce attrition, upgrade human capital and drive innovation, improve customer service and sales, and hire high-performing people. ${ }^{45}$

b) Enhancing the Adversity Quotient (AQ) by using Qur'anic Management Method.

The founder of AQ argues that AQ can be enhanced by listening to our response to adversity, exploring all origins and our ownership responses, analyzing the evidence, and doing actions. ${ }^{46}$ In addition, Al-Qur'an also offers a scientific way to

${ }^{43}$ Stoltz, P.G. 1997. Adversity Quotient: Turning Obstacles into Opportunities. John Wiley and Sons, USA., ISBN: 0-4711-7892-6.

${ }^{44}$ AQ; An Emerging Determinant Of Success and Superior Performace (http://stitchestm.blogspot.com/

2007/09/adversity-quotient-aq-emerging.html).

${ }^{45}$ What is $A Q$ ? ( http://www.peaklearning.com/ , downloaded at 1 st Descember 2008), p. 1.

${ }^{46}$ www.peaklearning.com. 
avoid halu' in human's life. After stating that mankinds is created so anxious (halu') in chapter Al-Ma'arij: 19-21, the Qur'an proposes qur'anic management method to address halu' so that human beings can free themselves from halu' negative influences as stated in Al-Ma'arij Chapter: verses 22-34.

This method is a series of over time continuous therapy which is able to increase the Adversity Quotient (AQ) in order to shield humans from psychological fragility. It is clearly stated in translated chapter of al-Ma'arij verses: 22-34 below:

"Except the observers of prayer(22) Those who are constant in their prayer (23) And those within whose wealth is a known right (24) For the petitioner and the deprived (25) And those who believe in the Day of Recompense (26) And those who are fearful of the punishment of their Lord (27) Indeed, the punishment of their Lord is not that from which one is safe (28) And those who guard their private parts (29) Except from their wives or those their right hands possess, for indeed, they are not to be blamed (30) But whoever seeks beyond that, then they are the transgressors (31) And those who are to their trusts and promises attentive (32) And those who are in their testimonies upright (33) And those who [carefully] maintain their prayer (34).

The verses above actually explain many benefits dealing with the problems mentioned. However, this discussion is limited to particular aspects namely to suppress the negative influences of halu' and to raise humans' optimism. The Qur'anic Management methods to improve AQ are as follows:

\section{1) Performing Prayers}

People who are able to dive into the meaning of prayer will be far from devastating pessimism. The positive words and statements spoken during prayer (salat) can give 'auto-suggestion' efects that can encourage people who speak it to act 
as they say.47 For example, the statement "inna shalati wa nusuki wa mahyaya wa mamati li Allahi Rabbi al 'alamin" (my prayer, my worship, my life, and my death are belong to God, the Lord of the world). If someone sincerely believes it as a personal statement, the auto-sugestion aspects of it will be tremendous, one of them is that all intentions and activities of life will be projected in the most appropriate focus (Allah, in His function as a Manager of the Universe).

Prayer contains of realistic physical motion combination. This symbol means that every Muslim is typically a man who is dynamic, always moving, not want to be quiet, moving forward and reaching achievements. In short, a muslim should own positive thinking, positive action and positive works. ${ }^{48}$

2) Establishing prayers continuously

Prayer continuity ${ }^{49}$ has impacts that all of prayer benefits can be obtained continuously throughout life (physical health, mental and conviction are affirmed on an ongoing basis). This ensures that optimism will continue to be encouraged throughout the ages.

3) Spending the property for infaq

The main benefit of this point is to kill al-khirshu (the greed) as the trigger of al-manu' (the unwillingness to give). Issuing infaq means that someone stops الجزوع (complaint) by

${ }^{47}$ Imam Musbikin, Rahasia Shalat bagi Penyembuhan Fisik dan Psikis: Terapi Religius (Secrets of Prayer for the Physical and Psychic Healing: Religious Therapy) (Yogyakarta: Mitra Pustaka, cet. I, 2003), p. 106.

${ }^{48}$ Imam Musbikin, Rahasia, p.105. Therefore, if there is no movement of prayer, just stood static, it is called death man's prayer. "Static condition means death", Muhammad Iqbal said. The series of physical movements in real prayer therapist impacts that are beneficial to the health of the body. Look at the research of Shaykh Hakim Abu Abdullah Ghulam Moinuddin through his book; The Book of Sufi Healing (Kitab al-Timm alRauhi al-Shufi). When a prayer is said seriously, it will clearly be able to affect the soul and body.

49 The commentators agree that the meaning of dawamah is continuity. See the interpretations as mentioned above. 
spending the wealth that they love. This is because the wealth spent can be very meaningful and useful to others. Our religion gives a great reward for this activity and God even guarantees in multiplied return. A good believer always remembers that charity will not decrease wealth. Thus, it will built up optimism to work more productively.

4) Believing in the Day of Judgement

Believing in the truth of the hereafter will raise a belief that all negative things such difficulties and bitterness are only pseudo-real things. The hereafter is the real place of happiness and the actual harvest of results. The convenience will grow enthusiasm and optimism to get through the difficulties, grow the spirit of achievement because believing in God's reward, and grow the courage to avoid wickedness because believing in the God's punishment. 50

5) Feeling Fear of the God's Punishment

Those who believe in God should not think about despair or even suicide. They will offer their life and best devotion only for the God. All forms of wickedness are avoided for fear of His anger. ${ }^{51}$ They do not like to to do nothing, complain, and withhold to give and share to others as they fear that He will be disappointed. He continues to work, produce, give benefits, and improve performance in order not to lose His blessing (ridla).

6) Having sexual intercourse only with a legitimate partner

The next verse specifically command to have sex only with a legitimate partner. Those who do it will gain happines as they throw complaint (الجزع) on her partner and are not greedy against the opponents sex, although physically they

${ }^{50}$ Compare with Hasbi al-Shiddieqy, Tafsir an-Nur Juz 29 (Jakarta: Crescent Star, Cet. I, 1973), p.82-83.

${ }^{51}$ Furthermore, al-Maraghi explained that a believer does not deserve to feel safe from the wrath of God, even though he was so obedient to Him. See al-Maraghi, Tafsir al-Maraghi, p. 127 
are more appealing. This is one way of therapy to repress the halu'.

Having sexual intercourse with wife/ husband can give some positive psychological benefits, including obtaining inner satisfaction (by gaining orgasm), increasing a sense of affection for couples (sex is an amorous affection activity), increasing self-esteem, repressing stress and growing optimism. ${ }^{52}$ It will also grow the spirit to maintain health, work hard and reach achievements as well as to give happiness to the couple.

7) Fulfilling the Mandate and Promises

Amannah refers to the fulfilment of the laws that God has revealed. These laws are referred to the trust emphasizing the fact that the undertaking obedience to God is something that is freely taken on by humans without any coercion, and that they now have duty of discharging that trust. ${ }^{33}$ Ibn `Abbās says that 'trust' refers to obligation. ${ }^{54}$ Fulfilling trusts in general means to discharge our duties to God, muslims, and His creation. ${ }^{55}$ Bukhārī and Muslim record Abū Hurayrah authority saying that Prophet Muhammad (peace be upon him) said, "The signs of the hypocrite men are three: when he speaks he lies; when he makes an oath he breaks it; and when he is entrusted with something he betrays that trust." Trustworthiness can be the greatest cause in increasing sustenance and

${ }^{52}$ Research conducted by Joy Davidson, PhD, psychologist and sex therapist in New York, proving some extra sex and more about the benefits of physical and psychic, including improving the health and performance of the heart, burn calories, improve the immune system, relieve pain, increase the risk of cancer prostate, strengthen the pelvic muscles, and help you sleep more soundly. See Angela Wika Citra Kusuma, Sex Hundred and One (Benefit) (http://www.angelawika.seks101.com/, downloaded November 10, 2008), p.1.

${ }^{53}$ al-Ālūsī, Rū $\hat{h}$ al-Ma ānīi [22/370]

${ }^{54}$ al-Qurțubī [14/162]

55 ibn 'Uthaymīn, Sharh Riyād as-Ŝalihīn [1/732] 
blessing. The Salaf would look to a person's amānah and truthfulness as indications of his religiosity rather than his prayer and fasting. Ibn 'Umar says "do not look to the prayer of anyone, nor his fasting, but look to the truthfulness of his speech when he talks, his fulfilment of trusts when he is entrusted, and his scrupulousness when he is given a position of responsibility". 56

8) Enforcing bear testimony

One of the characteristic of the believers is enforcing bear true testimony. Bearing witness is most significant pillar in administering justice in society. They inquire as to the reasons behind bearing testimony against people entailing in their animosity and thereby creating problems for themselves. Such people are indifferent toward human rights, devoid of social spirit, and irresponsible toward administration of justice. It is in this vein that the Holy Qur'an recurrently calls Muslims unto bearing true witness and regards its concealment as a sin. The issue is of particular significance in Islamic law serving as the pillar of proving many an individual and social law governed by particular laws and rulings. Islam orders the Muslim to be honest to himself and others. This order repeatedly comes in the Noble Qur'an and the sayings of Prophet Muhammad (SAWS). Islam orders the Muslim to tell the truth even if it is against the teller's interest. Orders him not to cheat or deceive other people. A Muslim is ordered by Allah to be honest in his words and deeds, privately and publicly alike.

9) Keeping the Prayers Quality

Keeping the prayer quality deals with two different word in prayer verses. The difference between دائمون (verse 23) and (verse 34) is that the first concerns with the implementation of prayers regularly and on time while the second is more focused on the implementation of shalat perfectly by

56 Bayhaqī [\#5278] 
maintaining its pillars, terms and sunnahs, and struggling to get rid of any seduction and temptation which relieves prayer humility. ${ }^{57}$

In the Qur'an, prayer is mentioned more than one which shows its ability in providing greater therapeutic aspects than the other worships. However, in principle, the whole points are intertwined in supporting therapy success. After humans are able to conduct such methods, they will live happily as stated in 35th verse of Al-Ma'arij chapter. The verse indicates the final goal of those who possess such characteristics. In the same manner, the preceding verses indicate the final goal of the sinners, the 35th verse reflects tersely that those who possess such characteristics shall dwell in the Gardens of Paradise and shall be cherished from all respects.

\section{Conclusion}

Semantics is about how the world's languages match forms to meanings. It invites to learning about ourselves and how we think, as well as acquiring knowledge that is useful in many different fields and applications. ${ }^{58}$

Halu' is a negative human potential to easily complain but hard to share with others because it is triggered by greed. It has potential to cause people to quickly give up, despair, and be selfish, thus causing self-difficulties to face challenges of life. It hampers an individual to be a strong personality and to achieve personal success. Therefore, human needs for specific methods to suppress and manage the negatif potential to avoid its negative effects.

Halu' and AQ (Adversity Quotient) had a very close relationship. Halu' could be overcome by improving the level of

${ }^{57}$ M. Quraish Shihab, Tafsir al-Mishbah, p. 447

58 Richmond H. Thomason, What is semantics? (http://web.eecs.umich.edu/ rthomaso /documents/general/what-issemantics.html) 
Adversity Quotient (AQ). Thus, a high Adversity Quotient (AQ) was the solution for the problem of human's halu'.

Halu 'and AQ (Adversity Quotient) has a very close relationship. Attitudes like easy to complain, reluctant to share for fear of his reduced, quickly give up and despair are the distinctive character of the owner of halu ' which can be overcome by improving the level of AQ. Thus, a high AQ is the solution for the problem of human's halu'.

The Qur'anic management methods in addressing halu' used to improve Adversity Quotient (AQ) were performing prayers, establishing prayers continuously, spending the property for infaq, believing in the day of judgment, feeling fear of the God's punishment, having sexual intercourse only with a legitimate partner, fulfilling the mandate and promises, enforcing bear testimony, and keeping the prayers quality.

\section{References}

Abd al-Rahman bin Kamal Jalal al-Din al-Suyuthi, Tafsir al-Dur al-Mantsur fi Tafsir al-Ma'tsur Juz VIII (Beirut: Dar alFikr, Cet. I, 1983).

Abu Abdillah Muhammad bin Ahmad al-Anshari al-Qurthubi (next; al-Qurthubi), Tafsir al-Qurthubi: al-Jami' li Ahkam al-Qur'an Juz 71 (Kairo: Dar al-Sya'bi, t.th.)

Abu al-Hasan Ali bin Muhammad bin Habib al-Mawardi alBashri, Al-Nukat wa al-'Uyun Tafsir al-Mawardi Vol VI (Beirut: Dar al-Kutub al-'Ilmiyyah, t.th.).

Abu Bakr Jabir al-Jaza'iri, Aisar at-Tafasir li al-Kalam al-'Aliy alKabir (Madinah al-Munawwarah: Maktabah al-'Ulum wa al Hikam, 1994)

Abu Zakaria Yahya bin Ziad al-Farra', Ma'ani al-Qur'an Juz III (t. tp.: Turatsuna, t. th.) 
Ahmad Musthafa al-Maraghi, Tafsir al-Maraghi terj. Bahrun Abu Bakar, LC., dkk Juz XXIX (Semarang: Toha Putra, Cet. II, 1993), p. 123.

Angela Wika Citra Kusuma, Sex Hundred and One (Benefit) (http://www.angelawika.seks101.com/, downloaded November 10, 2008).

Baum, J.R. and E.A. Locke. 2004. The relationship of entrepreneurial traits, skill, and motivation tosubsequent venture growth. J. Applied Psy., 89.

Dr. Ahmad Ibrahim Muhana, Al-Insan ( ).

Green, A. 2006. Effective personal communication skills for public relations. Creative print and design, USA. ISBN: 07494-4407-X

Hasbi al-Shiddieqy, Tafsir an-Nur Juz 29 (Jakarta: Crescent Star, Cet. I, 1973).

http://humanscience.wikia.com/wiki/Positive_and_Negative_Human_Traits

http://mohmansurfauzi.blogspot.com/2014/11/pendekatan-semantik-dalam-kajian-islam.html

http://www.medicaldaily.com/human-nature-optimisticpeople-use-more-positive-words-negative-10-different321442

https://sites.google.com/a/sheffield.ac.uk/all-about-linguistics/branches/semantics/what-is-semantics

Ibnu Mandzur, Lisan al-'Arab al-Mukhith Vol II (t. tp.: --, t. th.). Imam Abu al-Fada' al-Hafidh Ibnu Katsir al-Damsyqi, Tafsir alQur'an al-'Adhim Juz IV (Beirut: Maktabah al-Nur al'Ilmiyyah, Cet. I, 1992) 
Naifah

Imam Abu Muhammad al-Husain bin Mas'ud al-Farra' alBaghawi al-Syafi'i, Tafsir al-Baghawi al-Musamma Ma'alim al-Tanzili Juz IV (Beirut: Dar al-Kitab al'Ilmiyyah, Cet. I, 1993)

Imam Musbikin, Rahasia Shalat bagi Penyembuhan Fisik dan Psikis: Terapi Religius (Secrets of Prayer for the Physical and Psychic Healing: Religious Therapy) (Yogyakarta: Mitra Pustaka, cet. I, 2003)

Koonthaisong, M. 2003. Some mental features that correlated to the Adversity Quotient. M.Ed. Thesis. Mahasarakham: Mahasarakham University, Thailand, unpublished document.

M. Jawwad Maghniyyah, Al-Tafsir al-Kasyif Vol VII ( Beirut: Dar al-'Ilm al-Malayin, Cet. I, 1970).

M. Quraish Shihab, Tafsir al-Mishbah: Pesan, Kesan, dan Kaserasian al-Qur'an Vol. 14 (Jakarta: Lentera Hati, 2002)

Muhammad Ali al-Shabuni, Shafwatu al-Tafasir Vol III (Beirut: Dar al-Qur'an al-Karim, Cet. II, 1981).

Reinhard Rapp, The Computation of Word Association: Comparing Syntagmatig and Paradigmatic Aproaches (University of Mainz, FASK. D-76711 Germersheim Germany, ucrel.lancs.ac.uk/acl/C/C02/C02-1007.pdf).

Richmond H. Thomason, What is semantics? (http://web.eecs.umich.edu/ rthomaso/documents/general/whatis-semantics.html).

Shaykh Hakim Abu Abdullah Ghulam Moinuddin ; The Book of Sufi Healing (Kitab al-Timm al-Rauhi al-Shufi).

Siti Chamamah Suratno, 2005, Ensiklopedi al-Qur'an Dunia Islam Modern Vol II (Yogyakarta: Dana Bhakti Prima Yasa). 
Stoltz, P.G. 1997. Adversity Quotient: Turning Obstacles into Opportunities. John Wiley and Sons, USA., ISBN: 0-47117892-6.

Sulaiman bin 'Amr al-'Ajili al-Syafi'i, Al-Futuhat al-Ilahiyyah bi Taudlihi Tafsir al-Jalalain li al-Daqaiq al-Khafiyyah Juz IV (Mesir: Mathba'ah 'Isa al-Babi al-Khilbi, t.th.)

Syaikh Ahmad al-Shawi al-Maliki, Khasyiyah al-Shawi 'ala Tafsir al-Jalalaini Juz VI (Beirut: Dar al-Fikr, Cet. I, 1988)

Syaikh Imam Abu Yahya Zakaria al-Anshari, Fatkhu al-Rahman bi Kasyfi ma Yaltabisu fi al-Qur'an (t. tp.: 'Alim al-Kutub, t. th.).

Theoretical Underpinnings of Vocabula;ry Learning and Teaching (http://cd1.edb.hkedcity.net/cd/eng/vocab09/ch1_3-2.htm

What is AQ? ( http://www.peaklearning.com/ , downloaded at 1 st Descember 2008). 
THIS PAGE INTENTIONALLY LEFT BLANK 